\title{
Study on Utilization of Agricultural Waste as Soil Stabilizer
}

\author{
Shriganesh S.Shinde \\ M.E. Student, Government college of Engineering, Aurangabad. \\ G.K.Patil \\ Associate Professor, Government College of Engineering, Aurangabad.
}

\begin{abstract}
In India the production of agricultural products are of huge quantity, but the creation of wastes from these agricultural products are not disposed properly. Which creates adverse effects on the environment such as air pollution, water pollution, which affect on human health. Hence the proper disposal of such wastes becomes necessary for ecosystem and it became challenge for engineers.

The aim of this paper is to utilize the agricultural wastes such as Rise husk or ground nut shell but due to its property of decomposing it is not possible to utilize it in its pure form hence we have to use ashes of these waste materials separately at $3 \%, 6 \%, 9 \%, 12 \%$ and $15 \%$ and carried out tests such as CBR and standard proctor tests for each percent. Hence there is a value addition to these two agricultural wastes serving the three benefits of Safe disposal of wastes, using as a stabilizer and return of income on it.
\end{abstract}

Keywords: Agricultural Wastes, RHA, GNSA, CBR.

\section{INTRODUCTION}

All the centuries are growing so rapidly, this growth will clearly see by the improvement in infrastructural facilities and transportation facilities. Foundation \& Pavement is very sensitive to the characteristics which provide the support for pavement or structure and problems associated with this further become far more critical, particularly in regions where the black cotton soils are there.

All the soils are not expansive soil and all expansive soils are not black cotton soil. Black cotton soil is considered as non-suitable for construction due to high swelling and shrinkage behavior of soil. The soil poses problems to the structure founded on them. Very destructive results caused by this type of soil have been reported in many countries. The disadvantages of black cotton soil can be overcome by improving with suitable materials and if these materials are of waste from any source then that will help to disposal from that source.

\section{II.MATERAIALS}

SOIL: The basic material used for experiment is Black Cotton soils, which are having main characteristics as swelling and shrinkage. They are very sensitive to changes in environment. Mostly such soil is not suitable for construction purpose, following are the basic properties of soil which is used for this project.

Table 1.1: properties of soil before modification

\begin{tabular}{|c|c|c|}
\hline SR. NO. & PROPERTY & VALUE (\%) \\
\hline 1 & Specific Gravity & 2.662 \\
\hline 2 & Liquid Limit & 66 \\
\hline 3 & Plastic Limit & 26.62 \\
\hline 4 & Plasticity Index & 39.39 \\
\hline 5 & Free Swell Index & 23.08 \\
\hline 6 & Optimum Moisture Content & 26.11 \\
\hline 7 & Maximum Dry Density (g/cm3) & 1.445 \\
\hline 8 & California Bearing Ratio Value & 2.39 \\
\hline
\end{tabular}


RISE HUSK ASH: Rice milling industry generates a lot of rice husk during milling of paddy which comes from the fields. This rice husk is mostly used as a fuel in the boilers for processing of paddy. Rice husk is also used as a fuel for power generation. Rice husk ash (RHA) is about $25 \%$ by weight of rice husk when burnt in boilers. It is estimated that about 70 million tons of RHA is produced annually worldwide

During milling of paddy about $78 \%$ of weight is received as rice, broken rice and bran .Rest $22 \%$ of the weight of paddy is received as husk. This husk is used as fuel in the rice mills to generate steam for the parboiling process. This husk contains about $75 \%$ organic volatile matter and the balance $25 \%$ of the weight of this husk is converted into ash during the firing process, is known as rice husk ash (RHA). This RHA in turn contains around 85 $\%-90 \%$ amorphous silica.

GROUND NUT SHELL ASH: The groundnut shell obtained worldwide. The next stage is to heat the groundnut shell in an electric muffle furnace at a temperature of $500^{\circ} \mathrm{C}$ to $600^{\circ} \mathrm{C}$ for 4 hours in order to produce the groundnut shell ash.

\section{METHODS AND RESULTS}

The weak subgrade soil is treated with the two wastes at 3\%,6\%, 9\%, $12 \%$ and $15 \%$ separately and for each per cent CBR test and standard proctor test is carried out .The results of these tests showed improvement in CBR value with the increase in percentage of waste, also the value of maximum dry density will also increases while the value of optimum moisture content will reduces with increase in the Percentage of waste.

Table 1.2: CBR value of soil added with waste

\begin{tabular}{|c|c|c|}
\hline \% of waste & CBR value of RHA & CBR value of GNSA \\
\hline 0 & 2.39 & 2.39 \\
\hline 3 & 2.86 & 2.55 \\
\hline 6 & 3.34 & 2.63 \\
\hline 9 & 3.82 & 3.02 \\
\hline 12 & 4.30 & 3.66 \\
\hline 15 & 5.09 & 4.30 \\
\hline
\end{tabular}

Graph-1.1: Variation of CBR value with different percentage of waste

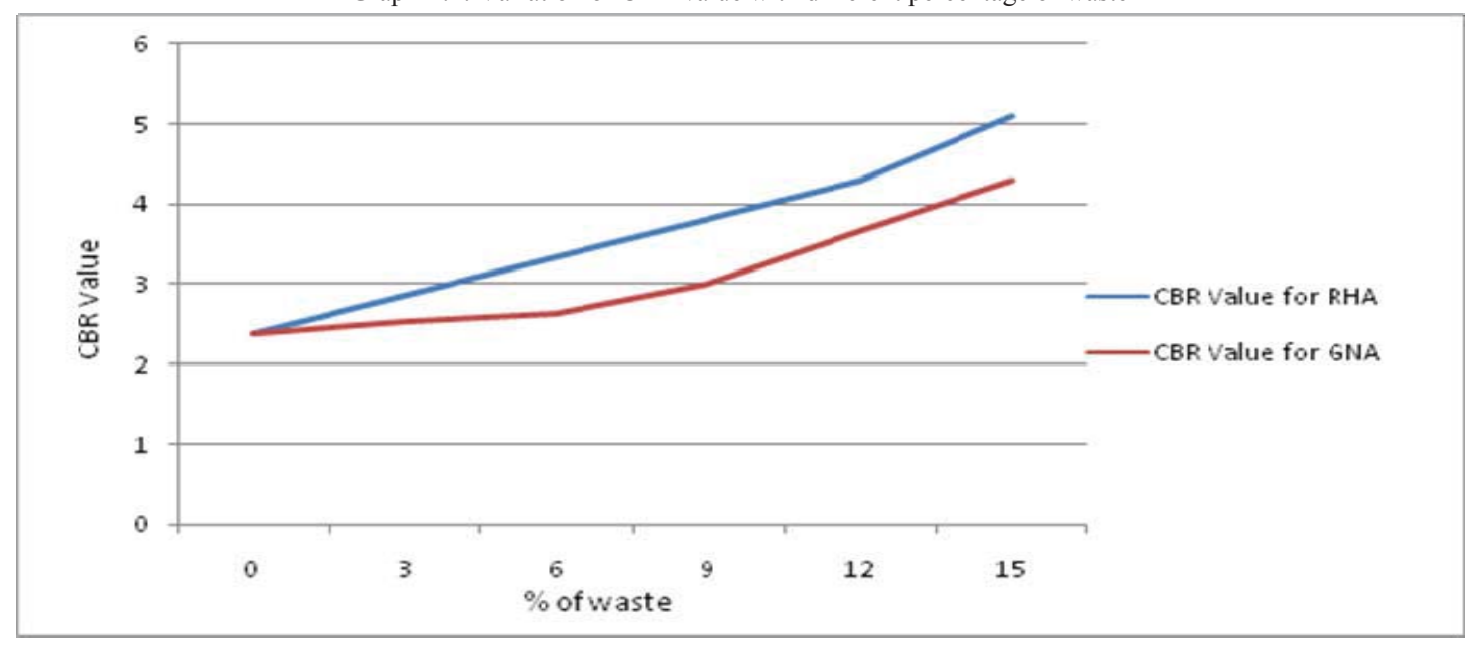

Table 1.3: MDD soil added with waste

\begin{tabular}{|c|c|c|}
\hline \% of waste & MDD value of RHA & MDD value of GNSA \\
\hline 0 & 1.445 & 1.445 \\
\hline 3 & 1.473 & 1.467 \\
\hline 6 & 1.500 & 1.472 \\
\hline 9 & 1.530 & 1.479 \\
\hline
\end{tabular}




\begin{tabular}{|l|l|l|}
\hline 12 & 1.566 & 1.483 \\
\hline 15 & 1.582 & 1.490 \\
\hline
\end{tabular}

Graph-1.2: Variation of MDD value with different percentage of waste

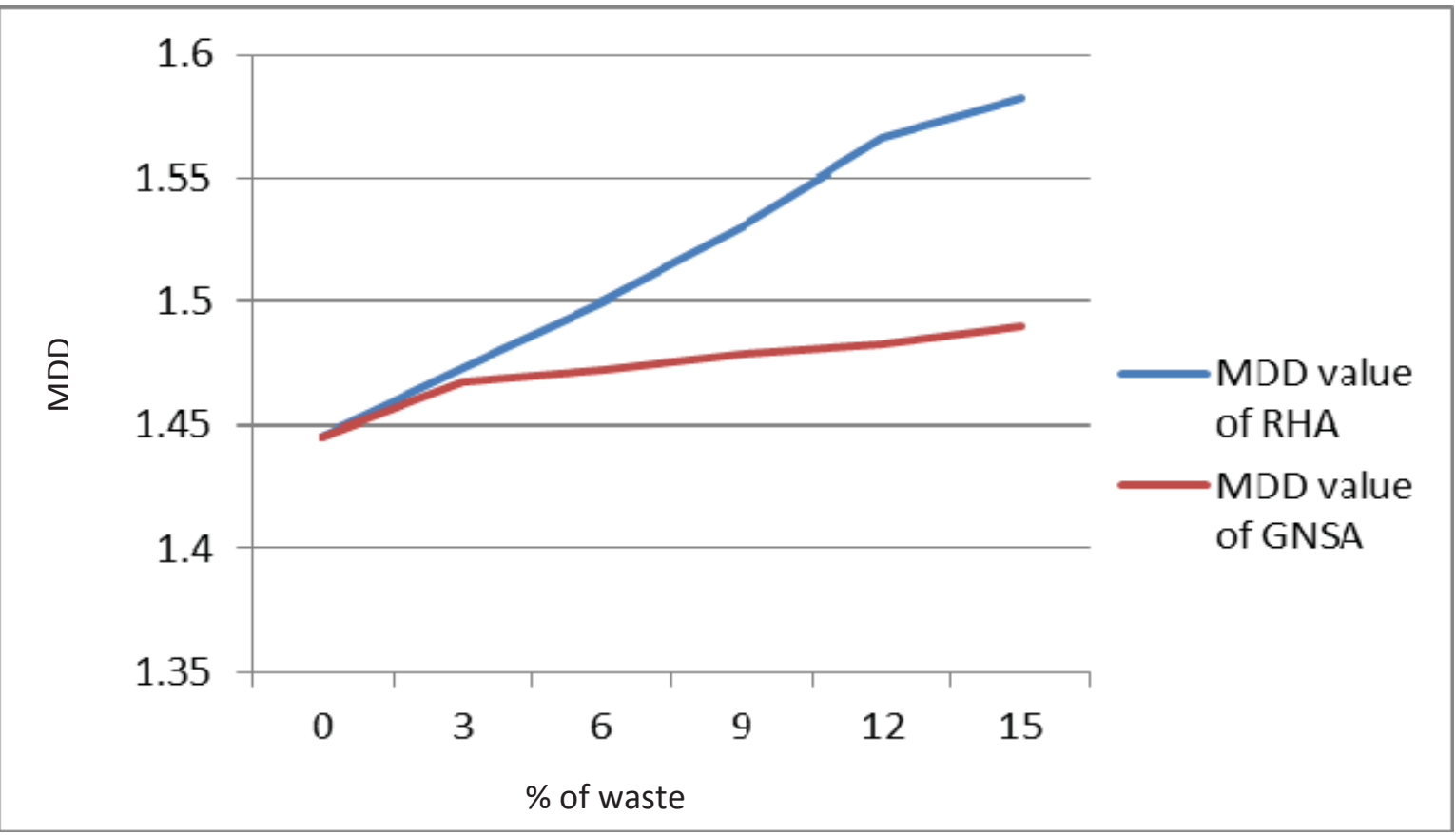

\begin{tabular}{|c|c|c|}
\hline \% of waste & OMC of RHA & OMC of GNSA \\
\hline 0 & 26.61 & 26.61 \\
\hline 3 & 25.29 & 25.77 \\
\hline 6 & 24.33 & 25.35 \\
\hline 9 & 23.49 & 25.12 \\
\hline 12 & 22.57 & 25.05 \\
\hline 15 & 21.67 & 24.84 \\
\hline
\end{tabular}

Graph-1.3: Variation of OMC with different percentage of waste

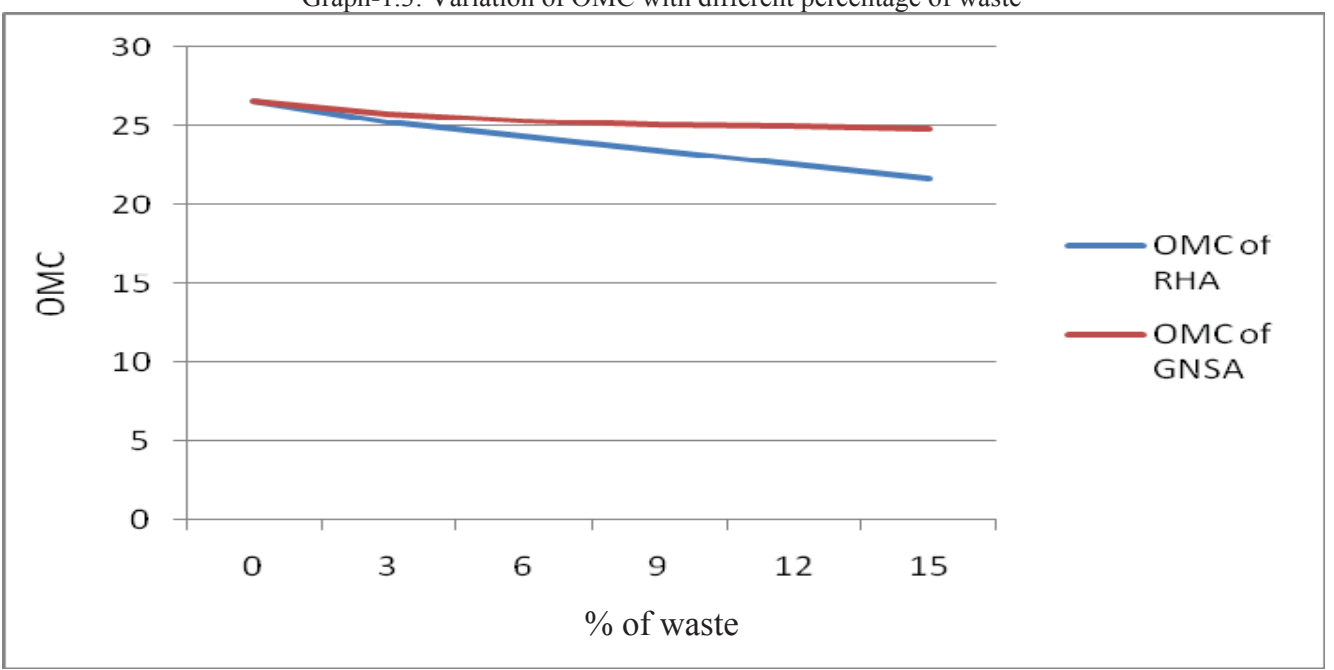




\section{CONCLUSIONS}

In India Production of large quantity of Agricultural wastes faces serious problems of handling and disposal. For doing Safe disposal of Agricultural wastes without adversely affecting the environment and the large storage area required are major concerns. Hence in our investigation an attempt has been made to utilize certain agricultural wastes such as RHA \& GNSA to stabilise weak subgrade soil. Use of these Agricultural wastes improves the Subgrade strength of the weak soil. Hence there is a value addition to these agricultural wastes serving the three benefits of Safe disposal of effluent, Using as a stabilizer and Return of income on it.

\section{REFERENCES}

[1] OriolaFolagbade and Moses George (2010), "Groundnut Shell Ash Stabilization of Black Cotton Soil" in EJGE Vol. 15.

[2] T.C. Nwofor and S. Sule ( 2012), "stability of groundnut shell ash (GSA)/ordinary portland cement (OPC) concrete in Nigeria"

[3] Ijimdiya, T.S. and Osinubi, K.J. (2011) “Attenuative Capacity of Compacted Black Cotton Soil treated with Bagasse Ash", Vol. 16, Bund. D in EJGE.

[4] Mohammed Abdullahi MU’AZU, "Influence of Compactive Effort on Bagasse Ash with Cement Treated Lateritic Soil"

[5] Methods of soil stabilization, December 24, 2010 [online] Available at: http://www.engineeringtraining.tpub.com/14070/css/14070_424.htm

[6] K. S. Gandhi (2012)“Expansive Soil Stabilization Using Bagasse Ash.” International Journal of Engineering Research \& Technology (IJERT) ISSN: 2278-0181,Vol. 1 Issue 5.

[7] Akshaya Kumar Sabat, (2012) "Utilization of Bagasse Ash and Lime Sludge for Construction of Flexible Pavements in Expansive Soil Areas" EJGE, Vol.17, Bund. H

[8] Fidelis O. OKAFOR and Ugochukwu. N. OKONKWO, "Effects of Rice Husk Ash on Some Geotechnical Properties of Lateritic Soil"

[9] Musa Alhassan (2008), Department of Civil Engineering, Federal University of Technology Minna, Niger State, Nigeria "Potentials of Rice Husk Ash for Soil Stabilization" AU J.T. 11(4): 246-250 